Article

\title{
What Role Does Rural Place Play in the Lives of Mid-Life Women in Sweden and Ireland?
}

\author{
Alison Herbert 1 \\ Irish Centre for Social Gerontology, Institute for Lifecourse \& Society, National University of Ireland, \\ H91 TK33 Galway, Ireland; alison.herbert@nuigalway.ie
}

Received: 5 October 2020; Accepted: 4 November 2020; Published: 6 November 2020

check for updates

\begin{abstract}
Rural place is a significant influencer of the ageing and states of well-being experienced by older women. This paper extends existing knowledge on gendered rural place by examining its influence on mid-life (45-65 years) women in rural Sweden and rural Ireland. This paper also examines rural place identity, self-identity and the enhancement of the self, and the multiple pathways to place attachment at mid-life. Qualitative data were gathered in 2019 from ten women living in Sweden's rural Värmland region, and in 2012-2013 from 25 women living in Ireland's rural Connemara region. Adopting a social constructionist approach within a lifecourse framework, methodology was informed by constructivist grounded theory, using one-to-one semi-structured interviews. These distinct studies show both similarity and difference in rural place identity and self-identity among mid-life women, and highlight nuances around place attachment, the home, social relationships, and the natural environment. The data show a compelling need for a greater consideration of the critical and diverse role rural place plays in shaping women's experiences of ageing and well-being both at mid-life and in older age.
\end{abstract}

Keywords: ageing; home; identity; Ireland; place attachment; rural; Sweden; women

\section{Introduction}

The aim of this paper is to explore and reflect upon how mid-life women in rural regions of two European States, Ireland and Sweden consider the role of rural place in their lives, of how they construct and experience rurality, and of how such constructions influence place and self-identity as well as levels of attachment to place and well-being. Whilst literature around rurality in social gerontology has moved on considerably from rural-urban discourse [1] and has come more to the fore $[2,3]$ in its own right, there still exists a relative dearth of empirical qualitative data that 'drills down' into 'lay-person' discourse, and particularly so amongst mid-life women. The added value of this paper lies in the emergence of rich qualitative data that look to explore participant perceptions of what it means to age within rural place. The physical geography of rural communities in both Ireland and Sweden, combined with diverse ethnic immigration, and a general urban-rural distinction in levels of socio-economic investment may be expected to evoke diverse narrative from research participants on what rural place means at a micro level. It is thus an aim of this paper to express what rural means to those who live in it, rather than to narrowly define the concept of rural.

Participants within these two studies were 'middle-aged'. As a growing population demographic across the western world mid-life women are still relatively under-researched. This matters on a number of fronts: for women, mid-life has been shown to be a pivotal phase [4] during which re-appraisals of earlier life and re-calibrations of future life may take place in an effort to maximise optimum potential and secure as good an old age as possible. Decisions taken around social relationships, health, work, and place for example at mid-life have the capacity to radically alter the ageing experience and quality of life outcomes both positively and negatively [5]. Wiggs [6] critiques the scarcity of literature on 
the lived experiences of late mid-life, post-menopause, but pre-old age women, stating that little is known about how women view their 'inner being' as they leave behind their reproductive years, and underscores the importance of listening to the actual lived experiences of women, and to the meaning they attribute to their lives in order to learn how to enhance quality of life in older age.

\section{Background to Research Areas}

Popular layperson perceptions of Sweden and Ireland include those of thriving cities alongside isolated, de-populated villages, townlands and islands. Ireland is often alluded to as an island off an island off the west of Europe, and Sweden as a 'spiritual and physical peninsula on the outskirts of Europe' [7]. Politically, both countries have mostly adopted a neutral stance regarding global conflicts, and both operate 'centrist' governments of coalitions. Sweden defines rural as areas with under 3000 inhabitants, has a population of around ten million persons and a population density of 24 persons per $\mathrm{km}^{2}$. Around $12 \%$ of Sweden's population lives in rural areas [8] compared to $42 \%$ of Ireland's population [9]. With a population of under five million, Ireland has a population density of 70 persons per $\mathrm{km}^{2}$ and defines rural as areas with under 1500 inhabitants. On the basis of these definitions Sweden would appear to be more rural than Ireland, yet Ireland is still considered to be the one of the most rural in Europe. Thus, it may be helpful to look beyond statistics and into the personal meaning of rural within these two countries.

Research for these two studies took place in the rural regions of Connemara in Ireland (see Figure 1), and Värmland in Sweden (see Figure 2). Geographically, the regions of Connemara and Värmland both 'look rural': almost 90\% of Värmland's landscape is covered in forest and 10,000 lakes. Värmland is land-locked and borders Norway to the west. Described as a 'deep place' in 'Connemara: The Last Pool of Darkness', by Tim Robinson, a world authority on the region [10], Connemara borders the Atlantic Ocean to the west, comprises coastal areas, islands, beaches, moor and bogs, presided over by the mountains of the Twelve Ben and Mamturk ranges. At around $1900 \mathrm{~km}^{2}$, Connemara, on the west coast of Ireland, is geographically much smaller in size than Värmland in west-central Sweden, at around 18,000 km². At around 300,000 persons, Värmland's population is much higher than that of Connemara, at around 32,000, yet each region has roughly the same population density of around $17 / \mathrm{km}^{2}$. Connemara's main town of Clifden, around which research took place, has a population of around 1600 persons. The town's nearest and largest city, Galway is some $80 \mathrm{~km}$ away and has a population of 80,000. Värmland's biggest city, Karlstad, comprises 88,000 persons, and is some $30 \mathrm{~km}$ away from the small town of Grums, where research took place. Grums town has a population of around 5000 persons. Lest we view Connemara in too romantic a light, it should be noted that it is a marginal landscape, both geographically and economically, and similar to some other remote rural parts of Ireland still carries the legacy of the Great Famine of the 1840s, which decimated the local population. Its history, like that of Ireland itself must be examined, as opposed to Sweden, in the light of its British colonial past, which although officially terminating around 100 years ago, still casts a shadow [10]. However, present day Connemara is not a homogenous region of 'pastness' as alluded to in some literature [11], but considerably more complex. Its southern Gaeltacht area in which Irish is the spoken tongue is quite different in tempo and nature to that of West Connemara, around the 'capital' town of Clifden, which is non-Irish speaking and has a semi-urban feel about it. What the region shares with Värmland is its peripheral geography, its under-population of an older demographic, and its status as an area requiring socio-economic intervention. 


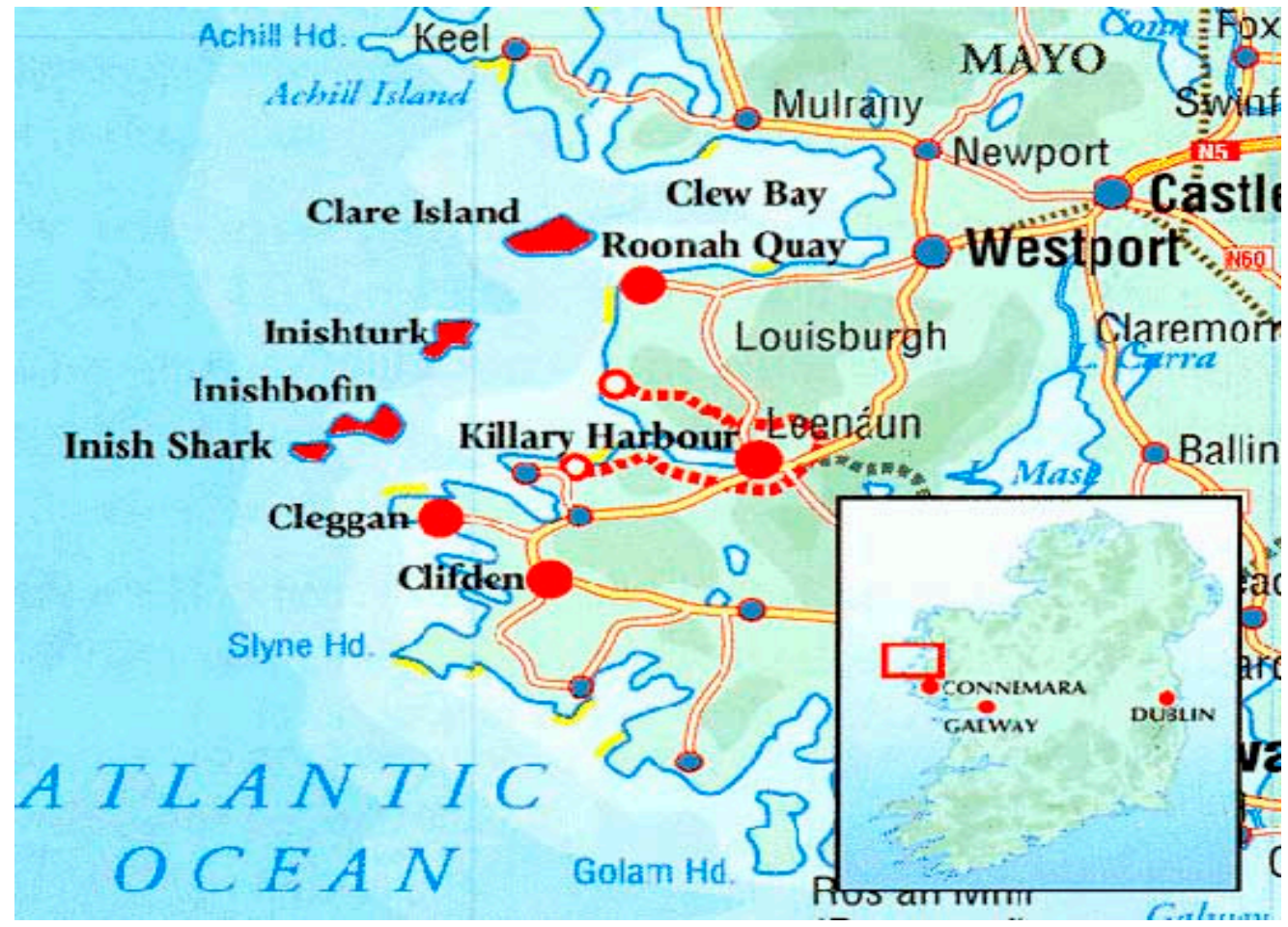

Figure 1. Connemara Region and main town of Clifden [12].

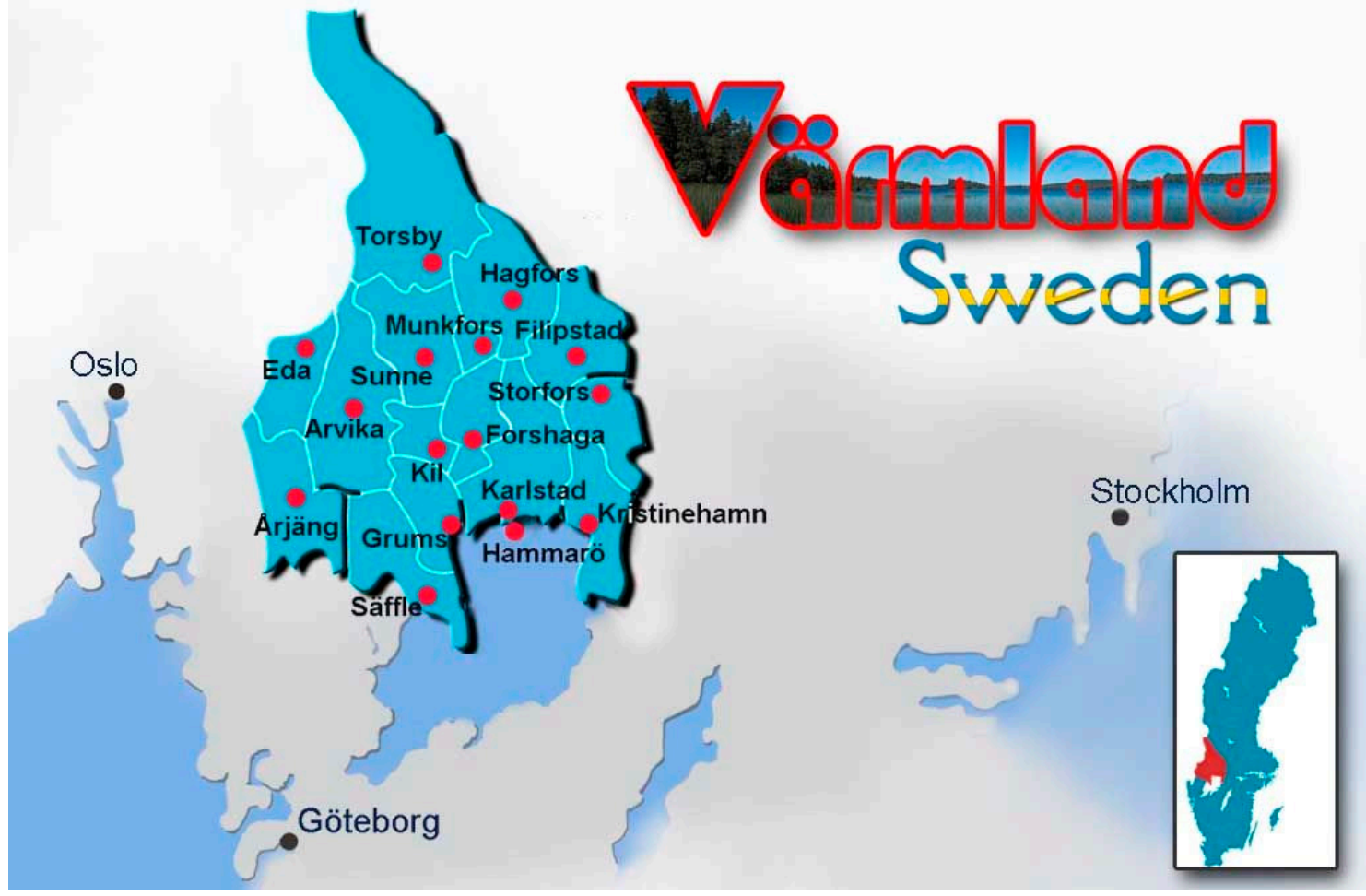

Figure 2. Värmland Region and town of Grums [13].

A contrasting factor between these two research sites is their proportions of older people. Whilst Sweden has an 'old' population, Ireland by contrast has a 'young' one [9]. Women at mid-life who are still in employment form over $70 \%$ in Sweden, although working hours decrease with age. Part-time, 
temporary employment has become more normalised and many are considered to be in involuntary unemployment. Some older women continue to extend their working lives by choice, but others from necessity. Despite its reputation as a country of great equality, women on average earn 86 per cent of men's wages [14]. Ireland was always a more traditional country than Sweden in its gendered approach to work, with gender-equality legislation not introduced until the country joined the EU in the mid-1970s. Prior to that period, the 'marriage bar' prevented women working in the public sector from taking employment.

\section{Literature Review}

Rurality as a concept is complex. Population and density statistics aside, rural may be also defined as a social representation with attached meanings $[15,16]$. The term rural may be utilised in quite different ways by different audiences. What academia or government understands to be rural may or may not converge with the layperson interpretation in any coherent way [17]. The term rural may never be used at all by those who live in rural areas, and yet those same people are nonetheless likely to have a clear understanding of what rural place means to them and how it influences their lived experiences. That understanding may be arrived at by their perceptions of the rural idyll [18], that is, what rural should look like. However; rural inhabitants, particularly women, who may experience additional inequalities [3] may also construct rural meaning through their understanding of what is available in the urban; it is, after all, not unusual to define one concept by its contrast to what it is not.

Place, and in particular rural place, with its distinct socio-economic features, has been shown to be a key influencer of quality of life [19] in both genders. Personal meaning and lay discourses of rural place $[17,20]$ may drive levels of attachment, and by extension the ageing experience. By seeking to understand what rural place means to women at mid-life and how they feel it may impact upon their older age, society may be better positioned to introduce measures and supports that augment a positive ageing experience.

The fluid concept that is rural [3] may be viewed as a social construct [16] or an imagined entity realised through particular discourses or ways of understanding. Rurality may become 'situated knowledge', produced by the experiences of individuals and reflective of, amongst other things, their age, gender, ethnicity, social class, and education. Lay discourses of rurality articulate how people in rural areas identify their locality as rural, who self-identifies as rural, and what comprises the fabric of rural place [21].

Self-identity [22] as a concept is shaped by a myriad of factors, including one's position in the social structure. This can be unpacked further by looking at individual identity as either self or social. Self-identity is composed in complex interaction with others; social identity refers to our recognition of and response to others' categorisation of us in terms of variables like gender, class, race, ethnicity, marital status and sexual orientation [23]. Notably, how the self is perceived has the capacity to determine whether an older rural woman identifies as 'rural' or not, which in turn may influence identity with place and levels of place attachment.

Rural dwellers are not homogenous in nature: they may enjoy aspects of the 'rural idyll' [18] but perhaps endorse its component parts differently. Close-knit community intimacy and personal recognition may be valued, but such properties may sit alongside a strong desire for personal privacy. Housing in rural Ireland and rural Sweden may be dispersed or otherwise, but the role played by rural neighbours in place attachment is likely to be culturally dependent by for example perceptions of societal individualism or collectivism [24]. Thus, levels of community intimacy will vary and will have the capacity to directly influence perceptions of belonging, or of feeling socially isolated, or even lonely in place. The stereotypical image of rural close-knit community may not have any direct relationship with a presence or absence of loneliness. Whilst some research supports the notion of rural intimacy and an absence of loneliness that is perhaps more prevalent in urban areas, other research suggests that the desire to be alone, perhaps even socially isolated, and yet not be lonely in rural areas is equally prevalent [25]. 
Rural place's natural aesthetic [26] is widely addressed in literature. However; rural place is defined by diverse factors, both positive and negative: fewer employment opportunities, lower incomes, reduced public transport, and fewer social and medical amenities are just some that tend to disadvantage older rural women in particular [27]. However, rural place may also be marked by positive features, including lower housing costs and cleaner environments [28]. The typical features of rural place, such as trees, hills, lakes, flora, fauna, and green and blue space are all positive features that contribute to the concept of the 'therapeutic landscape', which is linked to enhanced well-being and quality of life [29]. A feature of therapeutic landscapes is 'palettes of space' in the forms of blue (water) and green (land) [30]. Blue care and the benefits of water environments for example have been strongly linked to positive mental health and psycho-social well-being [31]. A sense of well-being gained from living near blue or green space may be sufficient to off-set any negative rural factors such as poorer social amenities and may increase attachment to place. The concept of landscape may also be considered as referring in a broader sense to an environment of connectedness, with no sharp division between the natural and the human or between self and place [32].

Place, and place attachment, are intricate concepts, which have been examined at length in the literature. Attachment to place is a cognitive-emotional bond to a meaningful setting and is related to a sense of cultural or symbolic 'belonging' and well-being. When disrupted, especially if forced, place attachment can negatively impact well-being [33]. It is a distinct type of connectivity that may manifest for example as physical/aesthetic, social/cultural, psychological and temporal [22]. The spectrum of attachment may range from complete alienation to complete solidarity but should perhaps be more accurately considered as various points along a continuum. However; it is likely that the sense of belonging or connectivity arising from attachment is connected to important forms of access, including community resources. It is this access that helps to produce a sense of place. Place attachment is particularly significant to older people as they may be more likely to remain in place and less likely to re-locate than other age groups, and connections formed between people and places are associated with quality of life and well-being in later life [1]. Women especially have been found to review their perspectives and behaviours at mid-life [4], and thus may take lifestyle-defining decisions regarding later life on how attached they feel to where they live. Attachment to place takes many forms; rural attachment may generally relate to nature bonding with the landscape, whilst physical attachment may relate to amenity-orientation such as local services. Psychological attachment relates to the meaning of place and influences well-being, whilst temporal attachment relates to an historical sense of place, perhaps induced by auto-biographical memory. Social or cultural attachment brought about by the building of local social capital [34] is perhaps the most widely recognised form due to its many manifestations such as community activities and social networks with neighbourhood, friends, family and significant others [22].

It is noteworthy that place attachment and identification are part of the same framework. Attachment is distinct from but related to the constructs of place identity and self-identity. Place attachment expresses the affective link between individuals and places, imbuing the meaning attributed to landscape and places; place identity relates to the cognitive component conceptualised in the Social Identity and Self-categorisation Theory, in which '... the acceptance of a particular self-categorisation shifts in ways that are consistent with the protection of contextually relevant levels of identity' [35] (p. 313). Place identity involves a psychological investment with place that appears to be time dependent, developing later than place attachment. These two concepts are co-related but are influenced by different elements. Literature argues that identification with place emerges more slowly than place attachment and may be closely related with self-identity [36].

Thus, we see that place is not an homogenised concept, but is experienced in multiple ways, and in interaction with other entities, such as people, objects, ideas, and other places [37,38]. Place is held to be space with meaning, as it incarnates the experiences and aspirations of individuals: it is people who give space meaning [16,39]. Place, as a socio-spatial phenomenon may also be perceived through the micro-system of individual; the meso-system of relationships with family and friends; 
the exo-system of relations with the wider community; and the macro-system encompassing the national [40]. Thus, house/home/garden/neighbourhood as well as national elements may all play a part in shaping perceptions of place and related ageing lives. In effect, we may 'wear our environment like a glove' as it 'literally becomes a part of our persona' [41].

The dual concepts of place in ageing and ageing in place [3] concede that where we age affects how we age, and by inference, the quality of life and levels of well-being [42] experienced in ageing. The nature of attaching to community, and the nature of belonging highlight their multiple sources, be those attachments physical, social, psychological, or temporal [22]. Manifesting as an emotional sense of deep connection with place that fosters a sense of identity and belonging, place attachment offers a significant source of meaning throughout the lifecourse [38,43]. Furthermore, attachment may arise from an emotional affinity with locations that have socio-biographical memories for the individual, whether indigenous or in-migrant $[19,33,44]$. Thus, place used by non-indigenous 'outsiders' for vacationing across the lifecourse may provide just as strong an affinity as to those indigenous to the area.

As place attachment is fluid over the lifecourse, it may be experienced differently at mid-life than in older age $[38,45]$, depending upon social context. How one ages and how one becomes attached to place appear to be inter-related but are nuanced. Do levels of attachment to place increase with 'good ageing', and if so, why? Or is the converse the case? Distinct pathways to connectivity between place and older people include: social attachment, aesthetic attachment, and amenity-environment-oriented physical attachment. Of particular importance to older women, who often find themselves living alone in later life, is amenity/environment-oriented physical attachment to place [20] in which the environment, be that positive or negative, becomes increasingly important to self-image. Will community environmental amenities available to us at mid-life, for example out-of-town supermarkets serve us in old age, and if not, how do we address this problem? Will a feeling of community belonging, strong whilst rearing children, wane in later life when family is absent? Will a tolerance of sub-standard housing or anti-social behaviour at mid-life become unbearable in older age when living alone? Understanding pathways to place attachment is crucial in addressing the social, physical, and psychological needs of older people, and can help to identify and address potential threats in the shape of migration, access to and quality of rural services, loss of social support networks, and rural development and change [20].

Place is closely linked to the concept of 'home', which is itself a matrix of social relations with wider symbolic and ideological meanings [37]. What makes place into 'home' relates to the concept of belonging [46], be that to the homestead or wider community, and strongly influences levels of place attachment across the lifecourse. One may be strongly attached to a house full of personal memories and artefacts $[38,47]$ but unattached to a neighbourhood full of strangers that is perceived as no longer having any personal meaning. Such a paradox makes it increasingly difficult to comprehensively assess levels of well-being.

A positive feature of rural place is its generally more affordable housing in relation to urban, and this also influences levels of place attachment. Whilst Ireland, akin to many European countries has seen a rise in the number of second home ownerships in rural areas [48], in Swedish culture owning a second home is particularly prevalent. This is particularly common amongst urban dwellers, who seek a second home in the countryside, but also popular amongst the rural population itself. Indeed, a number of studies on place attachment relate to summer houses and non-permanent residences [34]. Aligned with the desire to own a second country home in Sweden, however modest and however close to the primary home, is the cultural attribute of valuing the outdoor life [49]. The Swedish housing market may be characterised by a high degree of government intervention alongside a low degree of direct government ownership [50]. Security of tenure is well protected in Sweden, making rental a popular choice at certain stages of the lifecourse [51], particularly in later life, if widowed or divorced. In addition, government emphasis in Sweden is on providing home supports that allow older people to continue living independently: only five per cent of those over 65 years live in need-based assisted living, despite an ageing population. Over the past 30 years senior housing has been built or developed 
for all people over 55 years, and extra care housing for those over 70 years. Over $40 \%$ of Sweden's housing stock is owner-occupied, with the remainder attributed to public housing, co-operative housing (often partly owned), and private rental [52].

In rural Ireland owner-occupied housing is the preferred choice over rented. A recent report from the National Economic \& Social Council [53] in Ireland shows around 75\% outright ownership of homes in those aged over 55 years; in contrast, owner-occupied housing for younger cohorts is lower due to limited financial access. Housing may act as a defined pathway to place attachment. For example, at mid-life rural women may choose to remain in rural place even if such a decision may not be compatible with requirements for 'age-friendly housing' in old age. Such a choice is as likely to be based upon social networks as on housing quality, and may include family $[54,55]$, friends [56,57], neighbours [58], or community [22,59,60]. Conversely, post-mid-life rural women may choose to eschew their portfolio of social relationships nurtured across the lifecourse, to enter a new form of housing, such as a co-housing community [61] that marries collective social relationships with individual freedoms: in Sweden known as the Bund [62]. Due to specific government housing policies in Ireland that favour market-led and property-developer led models [63] supplies of public and private rental accommodation are low, and do not go anywhere near meeting demand. If owner-occupation becomes a less common form of tenure, as is becoming the case among large numbers of younger adults-'generation rent' [64] it may leave future generations of older people in Ireland at high risk of being unable to secure sustainable and affordable housing in later life [53].

\section{Methodology}

Discourse around the roles that rural place plays in the lives of mid-life women in Ireland and Sweden are explored in this paper through qualitative data, but such articulation could also be approached quantitatively in literature by using for example a semantic differential scaling technique in which research participants express rural descriptors along a continuum [65] in order to help determine 'weighting' behind a descriptor, and resulting in an 'equivalence of meaning'.

Qualitative semi-structured interviewing was considered to be the most appropriate method from which to explore, through open-ended questions, the role played by rural place in influencing the lives of mid-life rural women. It was the intention to listen, observe and endeavour to get the 'story behind' [66] participant narrative on the role of rural place in their lives. Alternative methodologies considered were that of the quantitative-qualitative interview in the research of older people [67], and the biographic-narrative-interpretive method [68], but the chosen method was considered to be a 'good fit' with constructivist grounded theory methodology, and the most appropriate to explore an under-developed area of social gerontology.

Research was carried out using a lifecourse framework [69], which acknowledges 'linked lives' in which socio-historical events have lasting effects on individuals, their relationships and their well-being over the lifetime. The course of life is perceived as being influenced at individual, cultural, social, natural, economic and political levels. Analytical principles of the lifecourse perspective are based upon everyday human experiences, inter-related life patterns and social links, and the influence of external contexts [70]. It is the interdependencies between the different dimensions of the individual's life that are capable of producing cumulative advantage and disadvantage [71], which serve to influence lived experiences past and ageing experiences still to come. A lifecourse perspective is particularly useful in informing and reforming public policies to better reflect actual lifecourse patterns in society.

As a methodology, constructivist grounded theory was chosen for its qualities as an excellent research tool for exploratory research: its explanatory powers can illuminate common issues that match theory with pragmatism. Other methodologies exist that may be useful, particularly in the research of participants for whom English is a second language. The 'life-story oriented interview strategy' for example allows for the natural emergence of interviewee stories, and the 'milestone technique' aids inarticulate participants through the use of artefacts [66]. An interpretive phenomenological approach was also considered for its reflective qualities, but as its greatest strength is in describing a 
complex phenomenon, this was rejected in favour of one in which multiple phenomena were likely to be aired. Grounded theory allows for an expansion of participation that other methods may lack. Constructivist grounded theory, employed in these two studies, attempts to explain social-psychological and social-structural processes within the context of social interaction [72]. Such social interaction is usually situated within one-to-one interviews, which become participant reconstructions of experiences and their meaning.

Grounded theory's systemic approach to analysis, including sampling, coding by gerunds, and memo-writing necessitate engaging in comparative, iterative analysis. Grounded theory interprets through raw data, rather than impression, and whilst it is not exclusively applied to qualitative research, as employed in these studies, it is considered a complete methodology, not just a starting point for further research $[73,74]$. As an analytical methodology, grounded theory seeks to construct inductive theory on issues of importance in people's lives and does so through theoretical sampling. Its inductive approach to research was initially developed by Glaser and Strauss [75], and its core dictates that the researcher begins with no preconceived ideas to prove or disprove. Grounded theory is an open, reflexive approach to research where data collection, analysis, the development of theoretical concepts, and the literature review occur in an iterative, cyclical process. While these features apply to some other qualitative research orientations, such as content or themed analysis, grounded theory has three distinguishing features. Researchers follow systematic, analytical procedures; researchers enter the research process carrying as few assumptions in advance as possible in order to discover emergent knowledge; and researchers do not just describe data, but conceptualise data in order to generate and develop theory [76-78].

In its examination of rural place, these two empirical studies adopt the social representation model of rurality [79], treating rurality as a social construct with its own subjective meanings. Whilst participants of these two studies recognised the geographical attributes of their rural place, such as hills, forests and lakes, and did not dismiss their influence, it was to the personal meaning of rural that participants turned to best explain their perspectives on place.

Participants of these two studies were at the mid-life stage of the lifecourse. Definitions of mid-life are fluid: the phrase first appeared in Funk and Wagnall's Standard Dictionary in 1895, in which the concept is defined as 'the part of life between youth and old age' [80]. Lay and scientific definitions of mid-life diverge, but mostly include the periods of mid '30s to mid '60s.

Data used in the Ireland study were taken from a doctoral thesis [5] that examined general perspectives on ageing amongst mid-life women in Connemara. Data for the Ireland study were collected between 2012 and 2013, using one-on-one interviews with a purposive, theoretically guided sample of 25 mid-life women (see Appendix A, Table A1 for details of Ireland participants cited in this paper). Data for this Sweden study were collected over ten days in 2019 using a diverse sample of ten women living in Värmland, Sweden, and employing the same interviewing technique (see Appendix A, Table A2 for details of Sweden participants cited in this paper). Recruitment of participants was achieved through stakeholders from the University of Karlstad, Sweden, and through The Swedish Rural Network [81]. Stakeholders in Sweden personally approached participants. Participants in Ireland were identified by diverse means: through personal contacts and snowballing, stakeholders and through print and broadcast media features, which raised awareness of the study. Participants of both studies were all white but were a mix of those born within their research areas, which is classified as 'indigenous' and those who migrated into the research areas, classified as 'in-migrant'. Regarding ethnicity, all participants of the Sweden study self-identified as Swedish. Participants of the Ireland study self-identified as Irish (18), French (1), German (1), English (2), Anglo-Irish (2) and American/Irish (1). Participants were not asked to state their income levels. Thus, it is not possible to identify levels of socio-economic class.

The difference between the two sample sizes is largely due to recruitment practices. Whilst the researcher controlled the selection of all participants to the Ireland study and had few time 
limitations, participants of the Sweden study were largely selected by stakeholders who had to control for proficiency in spoken English and availability within the allocated research timeframe.

Ethical approval for the Ireland study was received by the Research Ethics Committee, NUI Galway in 2012 and for the Sweden study by the same Body in 2019.

\section{Findings and Discussion}

\subsection{Defining Rural}

As illustrated in the literature review no one definition of 'rural' is relevant to every culture. What is more relevant to social gerontology than debating the difficulties around defining such terms as rural and countryside, is that of being mindful that rural should not be used simply as a backdrop to research but be an implicit part of it [82]. Perceptions of rural in both the Ireland and Sweden studies draw on the social representation model of rurality [15]: rurality becomes the meaning attached to it, be that the degree of proximity to neighbours, or the social infrastructure of health and transport services. Participants in both studies defined rural through their senses, referring to a slower pace of life, a greater sense of space, an increased sense of personal recognition and intimacy, and a visually more appealing landscape. Particularly in Sweden, participants spoke of biotic (flora, fauna) and abiotic (topography, geography, geology, climate) properties [83] that bonded them to their rural place. These properties were extended by participants in both countries, but primarily in Sweden, to include animals and birds, forest and forest foods, rivers and lakes, flowers, trees and hills.

Diversity around the definition of rural is illustrated by one participant of Connemara's main town, Clifden, in terms of proximity to neighbours and levels of social amenities. Penny, an in-migrant to Connemara reflects the stereotypical image of rural of dispersed housing with few or no neighbours, served only by a few, small, localised shops, and thus questions whether her place is rural at all:

'I don't really consider Clifden rural any more. If I was out in the middle of Carna (a small village) I wouldn't like that. I like to have neighbours. When the kids were young and I had to bring them to school in the mornings I couldn't believe there wasn't a shop open [in Clifden]. You had to go home and come back out to do your shopping, but I don't find it rural at all now, it's full of supermarkets.' [Penny, Irish, 59 years, outside town]

Conversely, another participant, living outside of the same town, did consider the area to be rural, as experienced through a socio-political orientation. Petrina, native to Connemara underscored how climate and weather can become negative features of rurality, and when combined with diminished public transport, form a pathway to rural social isolation:

'I would say we're very isolated politically. We feel it here, especially during the two bad winters, even the bus couldn't run. Then you feel isolated. If someone living in a very rural area 20 miles from Clifden or wherever cannot get to the chemist to pick up a prescription ... ' [Petrina, Irish, 48 years, outside town]

As in the Ireland study, participants in Sweden were divided on the degree of rurality of place. The town of Grums, with a population of 5000 was described by most as rural, but by some as semi-rural, although all participants agreed that the greater Värmland hinterland was rural. Only $30 \mathrm{~km}$ away from Värmland's largest city of Karlstad, Grums was defined largely by its biotic qualities. Olga, native to Grums defines rural in terms of biotic and abiotic features, as well as by living in a relatively small place in which she can easily access amenities:

'We have the nature-and that is rural to me, the forest very near, the lakes, the sea of Vänern. I think all of that is rural. And here in Grums it is small, everything is very near, and in my world that is rural.' [Olga, Swedish, 65 years, in town] 
Yet another participant, described this rural place as a hybrid, but evaluated its qualities, not in terms of amenities, but as feelings generated. For Tanya, who was from the areas, but had worked abroad for many years in cities, rural was a concept through which she felt its aesthetics in a sensory fashion in which rural promoted well-being:

'When you look at rural your eyes get rested -it is not square and hard, it is soft and moving. Grums is both. The centre is not so rural, but the surrounding area of the countryside is. [Tanya, 49 years, outside town]

\subsection{Place and Identity}

As stated in the literature, the process of identifying place as rural and the self as rural relies on a complex set of perceptions. What is critical is to understand place and identity from an intersectional perspective. A total of 35 women were interviewed over the two studies, with each one having unique intersections of influencing factors. When participants speak of place, place identity or self-identity, they draw on lived experiences across their lifecourse as well as on the variables that shape them, including age, education, income, nature of work, marital status, location of residence, race and ethnicity, amongst other demographic factors. Each of these variables intersects to create a palette that is unique to its 'owner'. This may sometimes make it difficult or even impossible to establish theory from narrative or to shape substantive theory into policy actions; nonetheless, each participant perspective augments understanding around the heterogeneity of older rural women and their relationship with place. Place is a social construction: space with individual meaning. Thus, it may be expected that how place is perceived by participants is influenced by the intersection of the multiple variables that shape their lives. Literature informs us that place is produced through symbolic and material struggles and historical practices that weave contested meaning [84], and particular cautions us against viewing place solely as an inert physical backdrop with fully-formed constructions ready to be 'used' by us, but instead to consider place as an enabler of the relationship between locality and identity [85]. Issues around place identity and self-identity are similarly complex and do not respond directly to any particular criterion. Although residence length has been identified as a strong predictor of place attachment [34], it is not the only one. Thus, a participant may express a strong place identity despite only living in the location for a short while. Conversely, another participant may report low place identity despite spending a lifetime in the same location. In a similar vein, it is sometimes difficult to define a location as rural simply because it meets relevant statistical criteria if it is perceived by participants to be only semi-rural. The social representation approach to rurality informs us that rural is defined by its attached meaning [15]. Identifying as a rural woman is perhaps the most subjective and fluid of all forms of identity relevant to this paper. No objective criterion can be exerted to aid definition. One participant may self-identify as rural, despite living much of her life in a town, whilst another may refute a rural identity despite living in a remote location. Understanding the 'self' of self-identity is to acknowledge that a diverse range of variables, accumulated over the lifecourse comprise the human make-up that forms identity [86]. Of particular relevance to ageing, the social identity theory helps us understand the complexities older women have around identifying as older [87], which adds another dimension for rural women on the perspectives of place.

Almost all participants of the Sweden study self-identified as 'rural women', although this identification was nuanced. Some participants identified strongly as 'Grums women', whereas others felt rural in a wider way, identifying more strongly with the Värmland region. Sarah raises the issue, commonly found in rural areas, of being identified as native/indigenous or in-migrant. It is a common rural theme to never be considered 'local', irrespective of length of residence. The repercussions of this may manifest as low levels of attachment to a place that others do not consider to be your 'real' home. Length of residence has been found to be closely related to place attachment through the construction of social relationships, particularly friendships. An increased number of friends may attach us to a location for longer, and the longer we stay the more friends we are likely to form, strengthening identity to place [36]. Interestingly, Sarah, like a number of participants more readily identified as 
belonging to the wider region rather than to the narrower concept of immediate place. Sarah worked in a nearby city, some $30 \mathrm{~km}$ away, and it may be the case that her absence for most of the week at work made her 'feel' somewhat less associated with Grums, her immediate place of residence, whereas she felt able to identify with the overall region that comprised both her home and her work locations. This underscores the complexities around the concept of place. Sarah does identify with her region and feels somewhat attached to this place, but not so much her small town:

'I think that people from Värmland are proud to be from this area. But I do not identify as a Grums woman, I think you have to be born here or be in school here to gain an identity. But I do identify as a Varmlänning.' [Sarah, 59 years, in town]

In contrast, whilst most participants of the Ireland study enjoyed living in Connemara and praised its scenic beauty, only one expressed strong place identity as a 'Connemara woman'. Rachael, although indigenous to Connemara, had travelled widely through work, and had lived in other European countries and other areas of Ireland. Thus, she could compare what her home place had to offer within a wider context. Rachael spoke passionately about her love of place, and of how upset she became when living elsewhere. Unable to confine the source of her attachment to a single entity, Rachael instead 'felt' that the region was her spiritual home and claimed to feel quite unwell when located elsewhere. Rachael's self-identity, as 'Connemara Irish', whilst unusual is not unique. Almost all participants of the Ireland study who were born or brought up in Connemara reported a strong affinity with the area. What singles out Rachael's self-identity may be her experiences of unhappiness when living outside of her special place. Rachael now enjoyed a happy relationship with the Connemara environment and her work, expressing high place attachment. Rachael worked in a riding stables, teaching and caring for the horses. Her love of Connemara was matched only by her adoration of animals, especially horses. Although not financially rewarding, her work with Connemara ponies underscores the interconnections of gender, environment and livelihoods in shaping identity [88]. Rachael's work, as well as her beloved rural place, synthesised to co-create her personal identity as an early mid-life feminist who acknowledged the gendered politics of ageing [89] valorised her 89 year-old 'hands-on' female employer, with whom she ran the stables and whom she considered to be a role model.

'Every single day I get up and go "thank God" because I absolutely eat, sleep and breathe Connemara, it's just what I am. I'm obsessed with it. If I meet somebody I cannot relax until I get to say "I'm from Connemara and I work with horses". After that I don't want to say anything else, as long as they know that's all there is.' [Rachael, Irish, 45 years, in town]

A strong self-identity within the community may be enough to forge place attachment, as illustrated by one Swedish participant. Janet was self-employed and well-known in the community through her various forms of work as a horse breeder and a local government Councillor. What she underscores is the very human desire to be recognised and to 'feel' a somebody, rather than an anonymous nobody. Such feelings would not be unique to rural place, but highlight a common perception that one is less likely to feel 'invisible' in rural place. Janet's self-identity as a successful businesswoman and public representative and place identity with Värmland are very much work-related. Janet recognised that she could carry out her horse business in a different region of Sweden, but not her government work. Furthermore, she had invested considerable time and resources into establishing her business and rearing her family in the Värmland region and was reluctant to relinquish the identity she had created for herself and her community recognition:

'In this area I have a name and am quite famous in horse circles due to competing, and my business. Here I am somebody, somewhere else I would be nobody. Everyone knows me, so I stick around. I have an identity here.' [Janet, 52 years, outside town] 
Almost all participants of these two studies were engaged in paid employment: being at the mid-life stage of the lifecourse most had not reached retirement age. There are multiple reasons why women work, both financial and non-financial, but it should be noted that the concept of work is very much gendered across the lifecourse [90]. Divergence in employment history, career interruptions to raise children or care for dependent adults and gender pay gaps all contribute to a higher risk of poverty in older age. Global rising pension ages, low levels of private pension contributions and other forms of savings has led to the relatively new phenomenon of the extended working life. Whilst relevant to both genders, working beyond retirement years is particularly applicable to women as they attempt to build up financial resources in later life, missed out on at earlier lifecourse stages through cumulative forms of disadvantage [71]. Some women enjoy the nature of their work and welcome the prospect of continued work into later life. As a result, their well-being is likely to flourish in older age. For others, the extended working life is an unwanted necessity, particularly for those in low-paid precarious [91] forms of employment. The health and well-being for such women diminishes in later life [92]. Whether work is a pleasure or a chore, what is clear is that the concept of work is closely linked to women's self-identity [93], and in some cases to place identity. Work is considered to be central to the self-concept, and may boost self-esteem by offering women an alternative identity to that of wife or mother, as well as safeguarding health and promoting longevity [94]. Equally, work may diminish both health and longevity in others depending on context. Employment in rural areas tends to be less diverse than in urban, so women may have to take whatever work they can secure, move around on an on-going basis 'following' work opportunities, or create their own employment.

Of the two participants cited above, Janet was self-employed and Rachael in paid employment. Both loved their work with horses, which had become part of their own individual identity and also partly supported place attachment. In a similar vein, the concepts of place identity, place attachment, self-identity and precarious work come together in the narrative from a visual artist, Denise, from the Ireland study:

'Only recently did I realise that there is a money aspect to my life, and I wouldn't have thought there was before. That's why I sometimes struggle to pay the mortgage. I have it for another 10 years and I wish I didn't, but I am managing to pay it on my own without any help. I always paid my own way. Hopefully I will get to pay my mortgage off, but I have no income really, and recently I was broke. I guess if I was completely bereft and I had paid my mortgage off I would get some kind of pension if it still exists. And maybe some kind of social security - and I had never worried about all of that before. That is a vulnerability for me.'. [Denise, 57 years, visual artist, single, dispersed area]

It is clear that this participant has chosen a path to follow at mid-life that unites her love of place and work. Whilst being cognisant of the fragile road ahead in later life as a single woman working in a precarious profession, she has still committed herself to full-time employment into old age as her work is her primary identity.

\subsection{Place and the Natural Environment}

Critical to definitions of rural and of the self are perceptions of the physical environment: literature argues that the establishment of the self is impossible without the context of place, and that landscape writing is autobiographical [32] (p. 3).

Aesthetic attachment is often linked to descriptors of the natural environment, such as scenic beauty, clean air, lakes and seas, wildlife, tranquility, and a sense of space. These rural qualities were expressed by a number of participants from both studies, although much more so by those of the Sweden study. However; one participant from the Ireland study, a visual artist, had travelled the world, but had chosen to work and live in a relatively remote part of Connemara for its aesthetic qualities:

'Water for me is terribly important... I treat the land like a sanctuary, it's beautiful. To look out at that mountain there-that's like a sacred mountain — the Mount Fuji of this territory. It reigns over 
this landscape, very powerful. The vista changes the whole time ... every morning I go down to the cliff and sit and look... and that is meditation for me, even if it's only for five minutes, and that is a priority that has entered into my life. Nature for me has always been a balm. Whether it's swimming in the sea or diving and meeting a Conger eel-actually that is heaven for me.' [Denise, 57 years, dispersed area]

Place attachment to the natural environment may emanate from the stress-relief and relaxation produced [33] as well as from the tactile and visceral feelings generated within the self, such as the sounds, smells and touch of nature, as illustrated by two participants of the Sweden study. Frances, like many Swedes, had a second holiday home, which she and her husband used regularly. Frances defined rural as offering her a quality of life unavailable elsewhere, a quality shaped by the natural world of the earth and water. She particularly relished her summer house as a retreat from a busy working life, and an opportunity to spend more time with her husband who had already retired from work:

'I am a happy person because of living here. I like my house, when I go home, I take off my shoes and step on the grass and enjoy. In both my houses (main house and holiday home). My houses matter. I swim every morning and use the boat. I have coffee in bed by my husband, and then a swim and then another coffee outside by the lake.' [Frances, 64 years, in town]

For Sweden participant Wilma rural place enhanced her mental well-being by quieting her mind, offering seclusion [33] and providing the space unlikely to be found in an urban area. Such positive comments mirror those in the literature of blue and green space [95,96]. Like most participants of the Sweden study, Wilma used the natural food resources around her, assimilating these into her daily life. It is the activities employed by Wilma that help to imbue this place with meaning and to create a sense of belonging [84]:

'I have the forest outside my house. I go often into the forest with my dog, picking berries and mushrooms. It is good for me-I can catch my breath, collect my thoughts. You don't have to talk to anyone, you can stay quiet. You can recharge your batteries. The forests are so vast you can get space.' [Wilma, 51 years, outside town]

Nature featured strongly as a restorative influence on participants in both Ireland and Sweden studies, enhancing place attachment [33], well-being and quality of life, as underpinned by Kaplan's Attention Restoration Theory [97]. The positive influence of nature on bio-psycho-social outcomes-from reduced blood pressure and enhanced attention to improved social interactions is underpinned by a number of studies $[26,98,99]$. As a country, Sweden boasts enormous tracts of forest (almost 70\% of land mass, mostly privately owned) and lakes (over 90,000); it is unsurprising then how deep is the respect for nature, and indeed direct interactions with nature have been found to positively contribute to social connectedness and providing meaning to life. Specifically, within the Sweden study, proximity to the natural environment and its high cultural values has been found to positively relate to neighbourhood satisfaction [100]. This is illustrated by Jenna, for whom nature directly influenced choice of place. In her earlier years, Jenna reported being happy to elsewhere, but as is often the case at mid-life, reviewed her future lifestyle trajectory in terms of benefits to her children and the cost of housing, and is now content living in Värmland:

'My partner and I walk a lot, we have beautiful spots for walking in the woods, and by boat to fishing and for fun. Fresh, clean air and a good swim. The children like to swim in the lake a lot. We are close to woods and the sea, so we chose to live here.' [Jenna, 45 years, in town]

Rural lived experiences are highly heterogeneous: one participant may perceive rural features as cultural capital to be enjoyed, whilst another perceives these as a business opportunity. Experiences may be polarised, but still enhance well-being and quality of life [26]. One participant of the Sweden 
study was strongly embedded in her rural environment, respected it, but chose to engage in the hunting of animals rather than using the environment in a more passive way. Tanya set about acquiring a rural skills-set that provided for her a certain rural identity [101] that may have been frowned on by other rural dwellers. Tanya was something of a paradox in that she closely identified with traditional Swedish rural pursuits such as hunting, but was eager to introduce socio-economic change that she hoped would open up traditional society, for example through the integration of immigration:

'I became a hunter of mainly deer. We eat the deer and use everything. When I started hunting I did not think I could do it, as I cry at everything, but it is a responsibility for me to do this. I love meat, and it is important that I understand where it comes from. I did not know if I could pull the trigger, but I read for a year and went out with my husband and his friends, and learned about respect and humility, and learned about the life cycle. Then I learned how to sew from the deer skin, small bags, some artwork. We use everything. I give some away as presents, but not for sale.' [Tanya, 49 years, outside town]

\subsection{Place and Social Relationships}

Social attachment to place underscores the human need for meaningful social relationships, and community intimacy proved to be an important concept within both studies. One participant of the Sweden study identified fully with her rural place and its people, considering herself highly attached and very much an 'insider'. For Olga, place identity conflated with self-identity and heightened her attachment to place:

'As I grew older I think this place means more and more to me. I like the people living in Grums, I understand them, I know them. And that means a great deal. I feel one of them. I feel at home here with the people. They are working class people and I am a working-class person.' [Olga, 65 years, in town]

Although social relationships enhanced Olga's attachment to place, this was not always the case. Some participants from both studies had difficulty identifying with their place, expressing either low or no levels of attachment, and felt like 'outsiders'. Their attachment, if present at all, was experienced through social relationships [33], but not necessarily those situated in their rural place, as illustrated by Mhari of the Ireland study:

'I am absolutely not-attached to here. I'd leave for an excuse, an idea, a plane ticket. Anything. I'm more attached to people than places. Like more than 99\% of my friends were not born and raised here, and we automatically seem to be on the same wavelength.' [Mhari, 45 years, outside town]

Connections between the concepts of 'insider' and 'outsider' may be based upon a number of factors, including length of residence and native versus in-migrant. However; it is not the case in either study that participant in-migrants feel like outsiders and natives feels like insiders. How participants self-perceive and are perceived by others may diverge and may be negotiated through degrees of involvement in local people's habitus [102]. Insiders are attributed to better understanding the way things are done, and thus fit in more easily than those who prefer to introduce change. This may partly explain the perception sometimes held by those who live outside of rural areas with a high place identity, such as Connemara and Värmland of 'backwardness' or living in the past. Some participants for the Ireland study cited below, including Mhari and Síle exemplify this. Mhari feels out of step with the local culture, despite living there all her life; Síle feels the same way as an in-migrant of some 30 years. Olga from the Sweden study on the other hand expressed a strong sense of the 'insider', not only because she had lived in the Grums region all of her life, but also because of her affinity to its people: she thought the way they thought. Along this spectrum of insider/outsider lie its many nuances, as illustrated by Tanya of the Sweden study, who self-identified as something of an 'outsider', due to having spent a good deal of time outside of Sweden but felt that her local community treated 
her a bit more as an 'insider' as they could identify her family history. Attachment to place by Mhari and Síle was low, and in both cases connected in part to their husbands. The relationship between husband and wife in each case had become increasingly fractured over the years as each husband had become more embedded and each wife less embedded in their rural places. For Olga place attachment was high, and for Tanya it was somewhat more nebulous. Interestingly, Tanya followed a traditional rural pursuit of hunting, which may demonstrate an 'insideness', but rented her home, which may be perceived as being uncommitted to place. This helps to underscore the varied nuances around the meaning of and the attachment to place, and to highlight how the quality of social relationships can both enhance and destroy place attachment.

Social relationships take many forms; one may feel attachment to place through family or friends but not through community members. Thus, deeper insight is needed into the make-up of relationships and their influence on the meaning of place.

A number of participants from both studies expressed place attachment through family members, but particularly so within the Sweden study. One participant, Joanna determined to stay in her rural place due entirely to the proximity of her immediate family. Her family supersede her location in influencing her well-being:

'I would not move too far from here, because I have my two sisters in Grums, and my daughter. That is important for me. I think Grums is good to live in. Why would I move? I know people here. Nature here I can find somewhere else, but my family, no. My grandchildren too-we can help them. If they are sick we can mind them, as their parents work.' [Joanna, 66 years, in town]

There was a large degree of consensus amongst participants of both studies on how their partners displayed much stronger attachment to place than they themselves did. It is interesting that in both studies there was a strong tendency for women to follow their male partners in choice of location and even to relinquish their own subsequent desires on where to live. It would appear that the husbands and male partners were more embedded in location than their female partners:

'He [husband] is even more involved in the community than I am. He is more Grums than I am. He would never consider moving from here. He knows everyone, and everyone knows him.' [Olga, 65 years, in town]

In Connemara, a few participants, for diverse reasons strongly wanted to leave their rural place, but could not secure agreement from their partners. It was almost always the case that these participants had followed their indigenous Connemara partners at earlier lifecourse stages. In such cases social relationships had become fractured, and place attachment weakened further. Síle and her husband had moved from Dublin, the capital of Ireland, to a remote part of Connemara with their young children and ran a guest-house for anglers. Now that her children had left home, Síle felt very little attachment to place. She acknowledged its wild unspoiled seclusion, clean air and pristine environment, but now considered her home area to be devoid of social amenities. However; she was unsuccessful in persuading her husband to move away to be closer to their grand-children:

'The stresses here are a lot less than living in an urban environment with the traffic. It's the clean air, we might have other problems, but we respect the environment. We have limited rubbish collection, so we compost, it influences how we live our lives and those of our children too-we grow our own veg. But, if my husband dies before me I would not stay here, I'd move. We have no public transport at all here and if I could no longer drive, I'd be trapped.' [Sile, 61 years, dispersed area]

Populations are becoming more geographically transient for a number of reasons including that of precarious work in which people are expected to move at short notice to new locations. In Ireland this has been met by an increase in renting over owning accommodation. In addition to short-term job contracts that require mobility of movement, escalating property prices, reduced access to credit, and household formation changes [53,103], including increased divorce-separation rates have all added 
to an increased demand for rental properties. Demand for rental properties is highest in urban areas where employment is largely located, but rural rentals have also increased in demand with some people living on the rural fringe [45] and commuting to 'work urban but live rural'. All these factors contribute to an increase in people 'on the move'. It is possible that neighbours, in the absence of immediate family or friends, could play a more central role in lives [104], and that we may increasingly rely upon them to perform tasks that otherwise might have been undertaken by significant others. If so, we may witness new pathways to place attachment forming. Of course, the converse is also true in that people may increasingly ignore their neighbours, seeing no point in nurturing what may be a short-term relationship. Some participants within the Sweden study referred to neighbours as a positive influence on well-being, and in some instances, an extension of family. Whilst participants in both studies paid attention to who their neighbours were, most in the Ireland study did not welcome any degree of intimacy. This was in contrast to participants in the Sweden study, who appeared to see a positive role for neighbours in enhancing well-being, and proved to be a strong influencer of place attachment:

'I have good neighbours, we go into one another's houses for coffee, and become like friends, and we look after one another's houses when we are travelling.' [Olga, 65 years, in town]

Whilst it is inaccurate to state that rural place produces higher degrees of community intimacy than urban place, anecdotally it often appears to be a 'given'. Participants in both studies spoke of the positive feelings of well-being associated with community recognition, and of how this increased their attachment to place.

'In small societies like this [Grums] we become closer to one another. We need to do things together and take care of one another. Like, we see if someone is away or sick or missing. You have the contact and you know about people. It's not the same in the city. Everyone where I live has been to the same school, and we know one another's children and their friends.' [Wilma, 51 years, outside town]

\subsection{Place and Immigration}

Early literature on rurality often concurred with the bucolic stereotype of community intimacy, traditionally associated with country living [105]. This social construction tended to embrace a nostalgic ideology of close-knit, caring communities in which neighbours co-existed in a spirit of 'meitheal' or collective help (see http://www.maryrobinsoncentre.ie). Such communities were perceived as safe but stationary, in contrast to those of the dangerous but dynamic urban. Such a perspective is now tempered with those arising from contemporary empirical research that demonstrates a more heterogenous approach to rurality [18], one in which the fear of the outside and outsider may still exist, but may have evolved in form from the simple fear of 'townies' to those from more 'alien' cultures. Both Ireland and Sweden have become more multi-cultural over the past 50 years, but Sweden in particular has attracted a large number of immigrant asylum seekers from outside of Europe, in contrast to mostly Eastern Europeans migrants in Ireland [9]. Currently, around 20 per cent of Sweden's population was foreign-born [52] in comparison to under 12 per cent in Ireland.

Sweden's relatively large-scale immigration has led to some societal division, as highlighted by two opposing perspectives on rural well-being in the Grums region of Sweden. Whilst both acknowledge current socio-economic ills as being relatively new to this rural region, the first participant, Janet conflates these with increased immigration, whilst the second participant, Tanya adopts a wider perspective. Both perspectives influence the revised meaning they attribute to place. Indeed, it has been argued that the everyday and institutional struggles over meanings may be viewed as a political action between state and citizens [106]. If citizens continually reshape themselves and their locations through relationships with state authorities [84], we may interpret in Janet's case a direct link between her struggle to make meaning of what she sees as a new socio-political landscape and her work as a local government Councillor in which she attempts to influence political thought and action on immigration: 
'There is a lower social class in the community now. Most people, like those who had an education, moved out of this area and left behind the less educated. The people left behind-there are more of them. They do not get through school and get a job. Everyone could have a job if they had the right mindset, but we have high unemployment with young people, which tells me that they do not want to work or are not capable of work. And it is inherited from generations. I hope that my children do move to Karlstad city or elsewhere.' [Janet, 52 years, outside town]

One may ask of course why mid-life women, like Janet do not move place if they feel so threatened by it, but humans are complex beings, and other factors had a role to play in her attachment to place, namely being widely recognised within the community for her various types of State and business work, and these took precedence.

Tanya on the other hand perceived the rural region's increased immigration as an asset, adding to cultural diversity, and thus enhanced her connection to place. Tanya constructed her meaning of a revised socio-political landscape from a different perspective to that of Janet, but in a similar fashion she used her employment as a facilitator in sharing community resources to influence outcomes. This underscores the literature that speaks to the diversity of meaning attributed to the same environment by different perceivers [36]:

'I think folk feel more threatened in rural areas. Immigrants may not want to come here, but are placed here in different municipalities, who are obligated to take a certain amount. There is a lot of racism here too, which I find really painful, as I have been given so much kindness around the world by people who did not know me and had no reason to be kind to me and they were. And then I come here to Sweden, one of the richest and best countries in the world, and people sneer about those with the darker skin. And it's more salient in small areas like Grums as they stand out. It's the fear of 'the other'-humans are programmed for that.' [Tanya, 49 years, outside town]

Neither Janet nor Tanya reported having any personal social relationships with immigrants, yet each had distinct standpoints based on what they observed; Janet's based on what she perceived as a threat to the traditional Swedish way of rural life and Tanya's as a possible enhancement that may help to open up rural culture.

\subsection{Place and Housing}

Housing plays an integral part in rural place attachment within the studies of Ireland and Sweden. Within the Ireland study in particular, there was a clear sense of the importance in later life of autonomy around housing and place should one's health diminish, and one becomes increasingly reliant upon others for care. In an ageing world, we may expect the concepts of the home and housing to become increasingly critical factors in the ageing process.

Attachment to place through the family house was common amongst participants of both studies. Some participants in Ireland had considered moving house at critical points over their lifecourse, for example to be closer to medical facilities for themselves or their partners, but had decided against doing so for reasons of high attachment to rural place. This is illustrated by one Ireland participant, Maebh who acted as an informal carer to her husband. Maebh's husband was becoming increasingly dependent upon her, and with no family in their rural area to turn to, she was tempted to move into the nearest city, Galway to avail of its hospitals and support systems and to be closer to her husband's family. As a symbol of continuity and order, security and refuge, attachment to home and place [34] directly influenced Maebh's decision on where to live, not just at mid-life, but also in older age:

'We have an ordinary bungalow, but on a beautiful site ... the whole place has such a vista. What would we be exchanging our home for? A beautiful place where's there's peace and calm to get a house on an estate, attached to someone else, or barely detached.' [Maebh, 53 years, dispersed]

In contrast to Maebh, one participant of the Sweden study, Rebecca felt attached to her house only, but not rural place. This is not so uncommon. Place has been defined as 'space with meaning' [39], 
and can there be a repository of meaning and memory greater than one's house, one's home? Rebecca expressed an attachment to her house more than to her place of residence, and in fact did much of her socialising in the nearest city, some $30 \mathrm{~km}$ away. Her 'settlement identity' as a rural woman may have been brought about by her high level of mobility [34].

'I am very fond of my house, it is home for me. We have a nice area at the back of the house with a pool. We use that a lot, but the children are getting bigger now. It would be difficult for me to sell the house, as I love it, but later, if the children move out, it would be difficult to be here without them. There are more restaurants and movies in Karlstad, so when the children have moved out we can maybe move there and we can walk, cycle everywhere and dine out and have a glass of wine.' [Rebecca, 46 years, in town]

One very strong influencing factor contributing to place attachment in the Sweden study was the affordability of rural housing and the ability to own rather than rent one's home [34]. All participants highlighted the low cost to buy or rent in comparison with urban areas; consequently, two rented and eight were owner-occupiers. A number of studies make clear the need for affordable, age-appropriate housing in rural areas to enable people to age in place [107]. Housing proved to be an area in which participants of the Sweden study anticipated government support. Sustainable, affordable housing [83] in older age was anticipated, supporting ageing in place. Great emphasis is attributed to ageing in place within social gerontology, although the literature does vary on this concept's degree of efficacy. The case may be made for example of the connection between ageing in place and well-being, as this may on occasion be better achieved by not ageing in place, but by re-location to accommodation that meets the desired outcome of enhanced well-being [108,109]. Within the Sweden study, most participants were optimistic about being supported by excellent social services that would allow them to age in their adapted homes. This was in contrast to participants in the Ireland study, who anticipated either no or low governmental help that would allow them to age well in their rural place, leaving them perhaps to seek support elsewhere from friends and family, or from non-governmental organisations [110].

\section{Conclusions}

The influence of rural place on the lived experience of older rural women highlights both similarities and differences across the two research studies. Nuances around a broader range of meanings and dimensions of rural and place are described rather than defined through the medium of participant discourses [111].

Some participants of both studies expressed concern over what they saw as the changing face of traditional rurality, largely in relation to a rise in increased ethnicities. In Sweden, new ethnicities display higher unemployment rates (https://sweden.se), a possible source of tension. Whilst some in the Ireland study only alluded to immigration in a general way, those in the Sweden study expressed more pointed views on what they perceived as its unacceptable consequences of deterioration in rural place. Whilst such participant concerns are real, and are supported anecdotally, empirical studies bearing out such negativities around immigration are more difficult to source [112]. Such concerns also underscore the critical acknowledgement of the rural countryside as a dynamic, not static force: rural women change with age, but so too does rural place.

Participants in each study expressed diverse degrees of place attachment. There are multiple pathways to rural place attachment, including those of place identity and self-identity. Whilst participants of both studies acknowledged lower population numbers and densities as indicators of rurality, it was the social representation model of rurality as a way of life that offered most meaning to them [79]. Thus, irrespective of size of village or town, or proximity to urban city, participants either 'felt' rural or did not, based on whether their perceptions of self and place met with their expectations to form a 'symmetry'. This underpins the subjectivity involved in defining rural: one woman's rural may be another's semi-urban, and such perceptions have implications across the lifecourse in terms of the role of place and well-being. 
Participants of both studies endorsed the importance of social relationships within rural community [60] in forming attachment or non-attachment to place, but nuances appeared to show a wider appreciation of community relationships amongst those of the Sweden study. Study participants in Ireland commended the role of community and neighbours in times of great need, such as funerals, but in times of normality, most participants preferred personal privacy and some degree of distance. Sweden's study participants on the other hand expressed the importance of identity and a sense of belonging, and many were socially involved with their neighbours. This may suggest no more than a cultural difference between a society leaning towards collectivist attitudes that incorporate 'lagom' or community consciousness such as Sweden [7] (p. 60) or an individualistic one such as Ireland [25], but perhaps also a deeper divide, as exemplified by the dichotomy of gemeinschaft and gesellschaft [113], which explores the nuances around communities and societies. Further research in this area may elucidate.

Some divergence between the two studies was found in the types of social relationship that influenced place attachment. Whilst participants in the Ireland study mostly cited female friends [57] as providing high levels of influence and identity, those in the Sweden study predominately cited family members [55] as being of critical influence in choice of place. Such a finding may be peculiar to this study, or perhaps again, a cultural difference. Further research may throw light on this area.

Partners played an important role in location and re-location of place, with consequences for place identity and attachment. A number of participants in both research studies had followed their partners to their rural place, usually through historical and family connections, which sometimes resulted in a stronger sense of place attachment by partners than participants. This is not problematic unless divergence arises in later life as to where constitutes 'home'. When a division exists between partners on attachment to place, the resulting consequences may be far-reaching when power disputes may arise [114].

The concepts of house and home in describing the importance of place and place attachment were cited by a number of participants of both studies, most of whom considered their house as integral to their ageing well-being [42]. What differentiated the findings was the level of confidence held by participants of the Sweden study regarding the availability of age-appropriate housing in later life. One striking difference in attitude between the two research studies was that the Sweden participants expected to receive high levels of housing support in older age to enable 'ageing in place' [115]. Houses and apartments are generally retro-fitted by government agencies and supported by social services to allow residents to live independently within their own homes; largely speaking, only those with an intellectual disability are admitted to residential care. Thus, participants of the Sweden study were assured of being cared for in their own homes in later life, which may lead to more sustained levels of place attachment across the lifecourse. In contrast to this, almost all participants of the Ireland study expressed anxiety over their future ability to live alone at home, anticipated little or no governmental help, and feared feeling compelled to enter residential care as a last resort.

Divergence between the two research studies around rural concepts was sometimes subtle but could also be stark. An outstanding difference in perception appeared around the degree of passion aroused by the natural environment comprising green [116] and blue [31] space. Whilst participants of the Ireland study, all living in a world-renowned beauty spot, Connemara, appreciated, but tended to understate its characteristics; participants of the Sweden study enthused wholeheartedly on the aesthetics of landscape, space and wildlife [33]. Attempting to compare two geographical locations is neither advisable nor useful: as we know, the devil is in the detail. Connemara's hills, beaches, loughs, and islands, not to mention its many social attractions are legendary. Whilst this was certainly cited by some participants of the Ireland study, both native and in-migrant, all participants of the Sweden study actively used their rural environment to enhance their well-being through daily forest walks, foraging, berry picking, boating, fishing, and in one case, hunting deer. In contrast, participants from the Ireland study appeared to experience their rural environment in a more passive manner, alluding to its fine qualities of fresh air and clean waters, but choosing to engage with nature in a more 
casual fashion-perhaps a daily stroll. There are any number of explanations that may account for such a divergence, but findings from this research suggest a much greater appreciation by Swedish participants of the role that nature can play in augmenting well-being and quality of life.

Having a clear understanding of the value placed on the natural environment and on other influencers of place can and should help to inform policy decisions [83] that support the well-being of older women in all environments, including rural. By appreciating the connections between rural place and attachment, we are better informed on how to plan and manifest environments that complement ageing. How rural women engage with nature, what they think of living in a rural environment, and how they feel rurality impacts upon their ageing and well-being can inform the discourse around therapeutic landscapes [29] in both rural and urban areas. If landscape and nature matter to the well-being of older rural women, it may be assumed that the natural environment also matters to those living and working in non-rural areas. What is good for rural ageing and well-being is likely to be good for all ageing [1] for example in the planning and restoration of natural environments near residential areas [96]. This may act as a strong supportive tool in achieving health and well-being [100].

In addition to the natural environment, understanding what rural actually means to older women, and the multiple pathways to place identity and attachment enables policy-makers and related interest groups to enact measures that can positively augment ageing at both mid-life and older age.

\section{Limitations}

These studies of mid-life women and rural place in Ireland and Sweden may have some limitations in terms of numbers of participants employed (25 in Ireland; 10 in Sweden), and in the comparison between two distinct, western European societies. Clearly, each country has its own cultural values, reflected in different socio-economic-political systems. Social norms in collectivist cultures, perhaps such as Sweden may produce different definitions and understandings of what rural place means in comparison to more 'laissez-faire' cultures, perhaps such as Ireland. In turn, reflections on the role of rural place in underpinning place attachment and well-being are likely to be viewed through different lenses. Some research shows differentials in political systems as influential in attitude formation [25]; other research demonstrates individual diversity within political systems that negates any generalisation of certain countries as either collectivist or individualist in nature [24,117].

All participants of these two studies are white; participants of the Sweden study all identified as Swedish. Participants of the Ireland study identified as either Irish, English, French, German, Anglo-Irish, and American-Irish. Each of these ethnic and race identities undoubtedly influences perspectives on rural place identity and rural self-identity. Whilst all participants in both studies identified as female gender, age identity was mixed, reflecting the nuances around social identity theory [87]. All participants were at the mid-life stage, identified by the researcher as $45-65$ years of age. Most identified as 'middle-aged', some did not consider themselves to be at the 'middle aged' yet, and only a few identified as 'old-aged'. However; the focus of this article is on the relationship between rural place and mid-life women. Thus, influencing factors such as race and ethnicity are acknowledged but not fully explored. This subject matter might be best dealt with through future research.

The aim of qualitative research is not to generalise, nor to necessarily identify patterns, but instead to simply understand the cross-cultural, intersectional lived experiences of participants. Thick, rich insights from these two studies offer data that may be examined alongside that of other European cultures and may prove of value to social gerontological literature and policy.

Funding: No funding was received for the Ireland study. The Sweden study was supported by a Royal Irish Academy Charlemont Grant.

Conflicts of Interest: The author declares no conflict of interest. 


\section{Appendix A}

Table A1. Demographic table Ireland study.

\begin{tabular}{|c|c|c|c|c|c|c|c|}
\hline Name & Age & $\begin{array}{c}\text { Location of } \\
\text { Residence }\end{array}$ & Employment & $\begin{array}{c}\text { Marital } \\
\text { Status }\end{array}$ & $\begin{array}{c}\text { No. } \\
\text { Children }\end{array}$ & $\begin{array}{c}\text { Born in Connemara } \\
\text { (I)/In-Migrant to Connemara (IM) }\end{array}$ & Race/Ethnicity \\
\hline Denise & 57 & Dispersed & Self-employed artist & Single & 0 & $\mathrm{IM}$ & White/Irish \\
\hline Mhari & 46 & Outside Town & Part-time administration & Married & 2 & I & $\begin{array}{l}\text { White/American } \\
\text { Irish }\end{array}$ \\
\hline Maebh & 53 & Dispersed & Full-time teacher & Married & 0 & $\mathrm{IM}$ & White/Irish \\
\hline Penny & 53 & Outside Town & Part-time administration & Married & 3 & $\mathrm{IM}$ & White/Irish \\
\hline Síle & 61 & Dispersed & Self-employed hospitality & Married & 3 & $\mathrm{IM}$ & White/Irish \\
\hline Rachael & 45 & Small Town & Full-time riding instructor & Partnered & 2 & I & White/Irish \\
\hline Petrina & 48 & Dispersed & Part-time care home assistant & Married & 2 & $\mathrm{I}$ & White/Irish \\
\hline
\end{tabular}

Table A2. Demographic table Sweden study.

\begin{tabular}{|c|c|c|c|c|c|c|c|}
\hline Name & Age & $\begin{array}{l}\text { Location of } \\
\text { Residence }\end{array}$ & Employment & $\begin{array}{l}\text { Marital } \\
\text { Status }\end{array}$ & $\begin{array}{l}\text { No. } \\
\text { Children }\end{array}$ & $\begin{array}{c}\text { Born in Värmland (I)/ } \\
\text { In-Migrant to Värmland (IM) }\end{array}$ & Race/Ethnicity \\
\hline Tanya & 49 & Outside Small Town & Full-time administration & Married & 2 & I & White/Swedish \\
\hline Jenna & 44 & Small Town & Full-time administration & Partnered & 2 & I & White/Swedish \\
\hline Wilma & 51 & Outside Small Town & Full-time administration & Partnered & 3 & IM & White/Swedish \\
\hline Rebecca & 46 & Small Town & Full-time administration & Married & 2 & I & White/Swedish \\
\hline Joanna & 66 & Small Town & Retired & Married & 2 & IM & White/Swedish \\
\hline Olga & 65 & Small Town & Retired & Married & 3 & I & White/Swedish \\
\hline Sarah & 59 & Small Town & Full-time lecturer & Married & 2 & $\mathrm{IM}$ & White/Swedish \\
\hline Janet & 52 & Outside Small Town & Self-employed horse-breeder & Married & 7 & IM & White/Swedish \\
\hline Frances & 64 & Small Town & Full-time social worker & Married & 0 & I & White/Swedish \\
\hline
\end{tabular}

Note: Small town denotes those living both within the town of Grums (5000 persons) and those living on its edge. Outside small town denotes those living more than $20 \mathrm{~km}$ from small town, but within the municipality of Värmland (281,000 persons). 


\section{References}

1. Rowles, G.D. What's Rural about Rural Aging? An Appalachian Perspective. J. Rural Stud. 1988, 4, $115-124$. [CrossRef]

2. Walsh, K.; Scharf, T.; Keating, N. Social exclusion of older persons: A scoping review and conceptual framework. Eur. J. Ageing 2016, 14, 81-98. [CrossRef] [PubMed]

3. Scharf, T.; Walsh, K.; O'Shea, E. Ageing in Rural Places. In Routledge International Handbook of Rural Studies; Shucksmith, M., Brown, D.L., Eds.; Routledge: London, UK; New York, NY, USA, 2016.

4. Lachman, M.E.; Teshale, S.; Agrigoroaei, S. Midlife as a pivotal period in the lfe course: Balancing growth and decline at the crossroads of youth and old age. Int. J. Behav. Dev. 2015, 39, 20-31. [CrossRef] [PubMed]

5. Herbert, A. What Are the Perspectives on Ageing of Mid-Life Women in Rural Ireland? Ph.D. Thesis, National University of Ireland Galway, Galway, Ireland, 2017.

6. Wiggs, C.M. Creating the Self: Exploring the Life Journey of Late Midlife Women. J. Women Aging 2010, 22, 218-233. [CrossRef]

7. Ruth, A. The Second New Nation: The Mythology of Modern Sweden. Nord. Voices 1984, 113, 53-96.

8. Sweden, S. Statistics Sweden. Available online: https://www.scb.se/en/ (accessed on 5 November 2020).

9. CSO. Cork, Ireland, 2016. Available online: www.cso.ie (accessed on 5 November 2020).

10. Wylie, J. Dwelling and displacement: Tim Robinson and the questions of landscape. Cult. Geogr. 2012, 19, 365-383. [CrossRef]

11. Edmondson, R. Rural Temporal Practices Future time in Connemara. Time Soc. 2000, 9, 269-288. [CrossRef]

12. Ireland, M. Map of Connemara. Available online: https://www.google.com/imgres?imgurl=http: //clifden.galway-ireland.ie/images/clifden-area-map.jpg\&imgrefurl=http://clifden.galway-ireland.ie/maps .htm\&tbnid=dG7r7W-LomxTZM\&vet=1\&docid=fFBxNDtnVOhj6M\&w=520\&h=445\&q=map + of + conn emara\&source $=$ sh/x/im (accessed on 5 November 2020).

13. Sweden, M. Map of Värmland. Available online: https://www.google.com/imgres?imgurl=https://vakantie huisjeszweden.com/wp-content/uploads/2017/12/map-accommodations-varmland.png\&imgrefurl=https: //vakantiehuisjeszweden.com/wp-content/uploads/2017/12/\&tbnid=dstG-yX8oOq0JM\&vet=1\&docid=Y hoG-a-Eo19oOM\&w=500\&h=334\&itg=1\&q=map + of + varmland + sweden\&source $=$ sh $/ x /$ im $($ accessed on 5 November 2020).

14. Krekula, C.; Engström, L.-G.; Alvinius, A. Sweden: An extended working life policy that overlooks gender considerations. In Gender, Ageing and Longer Working Lives: Cross-National Perspectives; Ní Léime, Á., Street, D., Vickerstaff, S., Krekula, C., Loretto, W., Eds.; Policy Press: Bristol, UK, 2017.

15. Halfacree, K. Talking About Rurality: Social Representations of the Rural as Expressed by Residents of Six English Parishes. J. Rural Stud. 1995, 11, 1-20. [CrossRef]

16. Mahon, M. New populations; shifting expectations: The changing experience of Irish rural space and place. J. Rural Stud. 2007, 23, 345-356. [CrossRef]

17. Jones, O. Lay Discourses of the Rural: Developments and Implications for Rural Studies. J. Rural Stud. 1995, 11, 35-49. [CrossRef]

18. Shucksmith, M. Re-imagining the rural: From rural idyll to Good Countryside. J. Rural Stud. 2018, 59, 163-172. [CrossRef]

19. Walsh, K.; Connolly, S.; Gavin, M.; Macuire, C.; McDonagh, J.; Murray, M.; O'Shea, E.; Scharf, T. Older People in Rural Communities: Exploring Attachment, Contribution and Diversity in Rural Ireland and Northern Ireland; Centre for Ageing Research and Development in Ireland: Galway, Ireland, 2010.

20. Hennessy, C.; Means, R.; Burholt, V. Countryside Connections: Older People, Community and Place in Rural Britain; Policy Press: Bristol, UK; Chicago, IL, USA, 2014.

21. Woods, M. Rural; Routledge: Abingdon/Oxon, UK, 2011.

22. Burholt, V.; Curry, N.; Keating, N.; Eales, J. Connecting with community: The nature of belonging among rural elders. In Countryside Connections: Older People, Community and Place in Rural Britain; Hagan Hennessy, C., Means, R., Burholt, V., Eds.; Policy Press: Bristol, UK, 2014; pp. 95-125.

23. Byrne, A. Developing a Sociological Model for Researching Women's Self and Social Identities. Eur. J. Women's Stud. 2003, 10, 443-464. [CrossRef]

24. Green, E.G.T.; Páez, D. Variation of Individualism and Collectivism within and between 20 Countries a Typological Analysis. J. Cross-Cult. Psychol. 2005, 36, 321-339. [CrossRef] 
25. McHugh Power, J.E.; Sjöberg, L.; Kee, F.; Kenny, R.A.; Lawlor, B. Comparisons of the discrepancy between loneliness and social isolation across Ireland and Sweden: Findings from TILDA and SNAC-K. Soc. Psychiatry Psychiatr. Epidemiol. 2019, 54, 1079-1088. [CrossRef]

26. Husser, E.K.; Roberto, K.A.; Allen, K.R. Nature as nurture: Rural older women's perspectives on the natural environment. J. Women Aging 2019, 32, 44-67. [CrossRef]

27. Richert, M.-J.D.C. Irish Women's Changing Status and Role in Rural and Urban Ireland from the 1970s to the End of the Celtic Tiger Era. Nord. Ir. Stud. 2013, 12, 127-146.

28. Brereton, F.; Bullock, C.; Clinch, P.J.; Scott, M. Rural change and individual well-being: The case of Ireland and rural quality of life. Eur. Urban. Reg. Stud. 2011, 18, 203-227. [CrossRef]

29. Williams, A. Therapeutic Landscapes: The Dynamic between Place and Wellness; University Press of America: Lanham, MD, USA, 1999.

30. Bell, S.L.; Foley, R.; Houghton, F.; Maddrell, A.; Williams, A.M. From therapeutic landscapes to healthy spaces, places and practices: A scoping review. Soc. Sci. Med. 2018, 196, 123-130. [CrossRef]

31. Britton, E.; Kindermann, G.; Domegan, C.; Carlin, C. Blue care: A systematic review of blue space interventions for health and wellbeing. Health Promot. Int. 2020, 35, 50-69. [CrossRef]

32. Meihuizen, E. Richard Murphy: Autobiography and the Connemara landscape. Literator 2015, 36, 1-7. [CrossRef]

33. Scannell, L.; Gifford, R. The experienced psychological benefits of place attachment. J. Environ. Psychol. 2017, 51, 256-269. [CrossRef]

34. Lewicka, M. Place attachment: How far have we come in the last 40 years? J. Environ. Psychol. 2011, 31, 207-230. [CrossRef]

35. Schmitt, M.T.; Branscombe, N.R.; Silvia, P.J.; Garcia, D.M.; Spears, R. Categorizing at the group-level in response to intragroup social comparisons: A self-categorization theory integration of self-evaluation and social identity motives. Eur. J. Soc. Psychol. 2006, 36, 297-314. [CrossRef]

36. Rollero, C.; De Piccoli, N. Place attachment, identification and environment perception: An empirical study. J. Environ. Psychol. 2010, 30, 198-205. [CrossRef]

37. Valentine, G. Social Geographies: Space E Society; Pearson Educational Ltd.: London, UK, 2001.

38. Degnen, C. Socialising place attachment: Place, social memory and embodied affordances. Ageing Soc. 2016, 36, 1645-1667. [CrossRef]

39. Tuan, Y.-F. Space and Place: Humanistic Perspective; Springer: Dordrecht, The Netherlands, 1979; Volume 20, pp. 387-427.

40. Burholt, V.; Winter, B.; Asrtsten, M.; Constantinou, C.; Dahlberg, L.; Feliciano, V.; Gierveld, J.D.J.; Van Regenmortel, S.; Waldergrave, C. A critical review and development of a conceptual model of exclusion from social relations for older people. Eur. J. Ageing 2020, 17, 3-19. [CrossRef]

41. Rowles, G.D. Habituation and Being in Place. Occup. Ther. J. Res. 2000, 20, 52S-67S. [CrossRef]

42. Gilleard, C.; Hyde, M.; Higgs, P. The Impact of Age, Place, Aging in Place, and Attachment to Place on the Well-Being of the Over 50s in England. Res. Aging 2007, 29, 590-605. [CrossRef]

43. Zhang, J.; Wang, B. Rural place attachment and urban community integration of Chinese older adults in rural-to- urban relocation. Ageing Soc. 2020, 1. [CrossRef]

44. Walsh, K.; O'Shea, E.; Scharf, T. Social Exclusion and Ageing in Diverse Rural Communities: Findings of a Cross-Border Study in Ireland and Northern Ireland; Irish Centre for Social Gerontology, National University of Ireland Galway: Galway, Ireland, 2012.

45. Mahon, M.; Fahy, F.; Ó Cinnéide, M. The significance of quality of life and sustainability at the urban-rural fringe in the making of place-based community. GeoJournal 2012, 77, 265-278. [CrossRef]

46. Rowles, G.D. Place and Personal Identity in Old Age: Observations from Appalachia. J. Environ. Psychol. 1983, 3, 299-313. [CrossRef]

47. Hannan, L.; Carney, G.; Devine, P.; Hodge, G. A View from Old Age: Women's Lives as Narrated through Objects. Life Writ. 2019, 16, 51-67. [CrossRef]

48. Norris, M.; Winston, N. Rising Second Home Numbers in Rural Ireland: Distribution, Drivers and Implications. Eur. Plan. Stud. 2009, 17, 1303-1322. [CrossRef]

49. Müller, D.K. The Attractiveness of Second Home Areas in Sweden: A Quantitative Analysis. Curr. Issues Tour. 2006, 9, 335-350. [CrossRef]

50. Innovation, T.C.f.H. Housing in Sweden: An Overview; UC Berkeley: Berkeley, CA, USA, 2017. 
51. Abramsson, M.; Andersson, E. Changing Preferences with Ageing-Housing Choices and Housing Plans of Older People. Hous. Theory Soc. 2015, 33, 217-241. [CrossRef]

52. Christophers, B.; O'Sullivan, D. Intersections of inequality in homeownership in Sweden. Hous. Stud. 2019, 34, 897-924. [CrossRef]

53. NESC. Homeownership and Rental: What Road Is Ireland on? NESDO, National Economic \& Social Development Office: Dublin, Ireland, 2014.

54. Arensberg, C.M.; Kimball, S.T. Family and Community in Ireland, 3rd ed.; CLASP Press: Ennis/Co Clare, Ireland, 2001.

55. Pearson Scott, J. Family Relationships of Older, Rural Women: Stability and Change. J. Women Aging 1998, 10, 67-80. [CrossRef]

56. Rose, S.M. Enjoying the Returns: Women's Friendships after 50. In Women over 50: Psychological Perspectives; Muhlbauer, V., Chrisler, J.C., Eds.; Springer: Boston, MA, USA, 2007; pp. 112-130.

57. Shapiro, P.G. Heart to Heart: Deepening Women's Friendships at Midlife; Berkley: New York, NY, USA, 2001.

58. Liebler, C.; Sandefur, G.D. Gender differences in the exchange of social support with friends, neighbors, and co-workers at midlife. Soc. Sci. Res. 2002, 31, 364-391. [CrossRef]

59. Neville, S.; Napier, S.; Adams, J.; Shannon, K.; Wright-St Clair, V. Older people's views about ageing well in a rural community. Ageing Soc. 2020. [CrossRef]

60. Peace, S.; Holland, C.; Kellaher, L. The Influence of Neighborhood and Community on Well-Being and Identity in Later Life: An English Perspective. In Home and Identity in Late Life: International Perspectives; Rowles, G.D., Chaudhury, H., Eds.; Springer Publishing Company: New York, NY, USA, 2005; p. 297.

61. Arrigoitia, M.F.; West, K. Interdependence, commitment, learning and love: The case of the UK's first older women's co-housing community. Ageing Soc. 2020, 1-24. [CrossRef]

62. Sandstedt, E.; Westin, S. Beyond Gemeinschaft and Gesellschaft. Cohousing Life in Contemporary Sweden. Hous. Theory Soc. 2015, 32, 131-150. [CrossRef]

63. Healy, T.; Goldrick-Kelly, P. Ireland's Housing Emergency_Time for a Game Changer; NERI WP 2017/No 41; National Economic Research Institute NERI: Dublin, Ireland, 2017.

64. McKee, K.; Moore, T.; Soaita, A.; Crawford, J. Generation Rent and the fallacy of choice. Int. J. Urban. Reg. Res. 2017, 41, 318-333. [CrossRef]

65. Osgood, C.E. The nature and measurement of meaning. Psychol. Bull. 1952, 49, 197-237. [CrossRef]

66. Chen, S.H.; Wei Qun Lou, V. Exploring the life experienes of less-educated rural older adults: Challenges and the possible solution-Life story interviews. In Researching Ageing: Methodological Challenges and Their Empirical Background; Luszczyńska, M., Ed.; Routledge: London, UK, 2020.

67. Czekanowski, P. Quantitative and qualitative interviews in older people research: Specificity and usability of the research tool. In Researching Ageing: Methodological Challenges and Their Empirical Background; Luszczynska, M., Ed.; Routledge: London, UK, 2020.

68. Wengraf, T. Qualitative Research Interviewing; SAGE: London, UK, 2001.

69. Elder, G.H.J. The Life Course as Developmental Theory. Child. Dev. 1998, 69, 1-12. [CrossRef]

70. Szatur-Jaworska, B. The lifecourse perspective in social gerontology. In Researching Ageing; Luszczynska, M., Ed.; Routledge: London, UK, 2020.

71. Dannefer, D. Cumulative Advantage/Disadvantage and the Life Course: Cross-Fertilizing Age and Social Science Theory. J. Gerontol. 2003, 58B, 327-337. [CrossRef] [PubMed]

72. Charmaz, K. Constructing Grounded Theory: A Practical Guide through Qualitative Analysis; SAGE: London, UK, 2006.

73. Charmaz, K. Teaching Theory Construction with Inititial Grounded Theory Tools: A Reflection on Lessons and Learning. Qual. Health Res. 2015, 25, 1610-1622. [CrossRef]

74. MacDonald, M.; Schreiber, R.S. Constructing and Deconstructing: Grounded Theory in a Postmodern World. In Using Grounded Theory in Nursing; Schreiber, R.S., Stern, P.N., Eds.; Springer: New York, NY, USA, 2001.

75. Glaser, B.G.; Strauss, A.L. The Discovery of Grounded Theory: Strategies for Qualitative Research; Aldine de Gruyter: New York, NY, USA, 1967.

76. Daymon, C.; Holloway, I. Qualitative Research Methods in Public Relations and Marketing Communications; Routledge: London, UK, 2002.

77. MacDonald, M. Finding a Critical Perspective in Grounded Theory. In Using Grounded Theory in Nursing; Schreiber, R.S., Stern, P.N., Eds.; Springer: New York, NY, USA, 2001. 
78. Morse, J.M. Situating Grounded Theory within Qualitative Inquiry. In Using Grounded Theory in Nursing; Schreiber, R.S., Stern, P.N., Eds.; Springer: New York, NY, USA, 2001.

79. Halfacree, K.H. Locality and social representation: Space, discourse and alternative definitions of the rural. J. Rural Stud. 1993, 9, 23-37. [CrossRef]

80. Lachman, M.E. Development in Midlife. Annu. Rev. Psychol. 2004, 55, 305-331. [CrossRef]

81. Network, S.R. Swedish Rural Network. Available online: https://enrd.ec.europa.eu/networking/nrn-profiles /swedish-rural-network_en (accessed on 5 November 2020).

82. Phillipson, C.; Scharf, T. Rural and urban perspectives on growing old: Developing a new research agenda. Eur. J. Ageing 2005, 2, 67-75. [CrossRef]

83. Wright, S.D.; Lund, D.A. Gray and green? Stewardship and sustainability in an aging society. J. Aging Stud. 2000, 14, 229-249. [CrossRef]

84. Caron, C. The subject of return: Land and livelihood struggles for place and citizenship. Contemp. South Asia 2016, 24, 387-399. [CrossRef]

85. Moore, D.S. Subaltern Struggles and the Politics of Place: Remapping Resistance in Zimbabwe's Eastern Highlands. Cult. Anthropol. 1998, 13, 344-381. [CrossRef]

86. Keith, J.; Fry, C.L.; Glascock, A.P.; Ikels, C.; Dickerson-Putman, J.; Harpending, H.C.; Draper, P. The Aging Experience: Diversity and Commonality across Cultures; SAGE: Thousand Oaks, CA, USA, 1994.

87. Chonody, J.M.; Teater, B. Why do I dread looking old?: A test of social identity theory, terror management theory, and the double standard of aging. J. Women Aging 2016, 28, 112-126. [CrossRef]

88. Harcourt, W. Gender and sustainable livelihoods: Linking gendered experiences of environment, community and self. Agric. Hum. Values 2017, 34, 1007-1019. [CrossRef]

89. Carney, G. Toward a gender politics of aging. J. Women Aging 2017, 30, 242-258. [CrossRef]

90. Ni Leime, A.; Street, D.; Vickerstaff, S.; Krekula, C.; Loretto, W. Gender, Ageing and Extended Working Life: Cross-National Perspectives; Policy Press: Bristol, UK, 2017.

91. Standing, G. The Precariat. Contexts 2014, 13, 10-12. [CrossRef]

92. Ní Léime, Á.; Ogg, J.; Rašticová, M.; Street, D.; Krekula, C.; Bédiová, M.; Madero-Cabib, I. Extended Working Life Policies: International Gender and Health Perspectives; Springer Open: Cham, Switzerland, 2020.

93. Biggs, S. The Mature Imagination: Dynamics of Identity in Midlife and Beyond; OUP: Buckingham, PA, USA, 1999.

94. Ní Léime, Á.; Ogg, J. Gendered impacts of extended working life on the health and economic wellbeing of older workers. Ageing Soc. 2019, 39, 2163-2169. [CrossRef]

95. Wheaton, B.; Waiti, J.; Cosgriff, M.; Burrows, L. Coastal blue space and wellbeing research: Looking beyond western tides. Leis. Stud. 2020, 39, 83-95. [CrossRef]

96. Pardoe, L. Recreating Parks: Securing the Future of Our Urban Green Spaces; Social Market Foundation: London, UK, 2020.

97. Kaplan, S. The restorative benefits of nature: Toward an integrative framework. J. Environ. Psychol. 1995, 15, 169-182. [CrossRef]

98. Russell, R.; Guerry, A.D.; Balvanera, P.; Gould, R.K.; Basurto, X.; Chan, K.M.A.; Sarah, K.; Levine, J.; Jordan, T. Humans and Nature: How Knowing and Experiencing Nature Affect Well-Being. Annu. Rev. Environ. Resour. 2013, 38, 473-502. [CrossRef]

99. Kaplan, R. The Nature of the View from Home. Environ. Behav. 2001, 33, 507-542. [CrossRef]

100. Björk, J.; Albin, M.; Grahn, P.; Jacobsson, H.; Ardö, J.; Wadbro, J.; Östergren, P.O.; Skärbäck, E. Recreational values of the natural environment in relation to neighbourhood satisfaction, physical activity, obesity and wellbeing. J. Epidemiol. Community Health 2008, 62, e2. [CrossRef]

101. Von Essen, E.; Tickle, L. Leisure or Labour: An Identity Crisis for Modern Hunting? Sociol. Rural. 2020, 60, 174-197. [CrossRef]

102. Moran, L. Negotiating boundaries or drawing the line? Transcending 'Insider/Outsider' distinctions in Connemara. Ir. J. Sociol. 2007, 16, 136-159. [CrossRef]

103. Cahill, N. The Implications of Covid-19 for Housing in Ireland; National Economic \& Social Council, Ed.; Irish Government: Dublin, Ireland, 2020.

104. Bowling, A. Good Neighbours: Measuring Quality of Life in Older Age; The International Longevity Centre-UK: London, UK, 2011.

105. Bell, D. Variations on the rural idyll. In Handbook of Rural Studies; Cloke, P., Marsden, T., Mooney, P., Eds.; SAGE: London, UK, 2006; pp. 149-160. 
106. Caron, C.; DaCosta, D. There's a Devil on Wayamba Beach: Social Dramas of Development and Citizenship in Northwest Sri Lanka. J. Asian Afr. Stud. 2007, 42, 415-445. [CrossRef]

107. UNECE, W.G.o.A. Older Persons in Rural and Remote Areas; UNECE: Geneva, Switzerland, 2017.

108. Vanleerberghe, P.; De Witte, N.; Claes, C.; Schalock, R.L.; Verté, D. The quality of life of older people aging in place: A literature review. Qual. Life Res. 2017, 26, 2899-2907. [CrossRef]

109. Wiles, J.L.; Leibing, A.; Guberman, N.; Reeve, J.; Allen, R.E.S. The meaning of 'Aging in Place' to Older People. Gerontol. 2011, 52, 357-366. [CrossRef]

110. ALONE. Housing Choices for Older People in Ireland: Time for Action; Supporting Older People to Age at Home; ALONE: Dublin, Ireland, 2018.

111. Mahon, M. Articulating perceptions of rural and urban-The use of semantic scales. Ir. Geogr. 2005, 38, 192-208. [CrossRef]

112. Vasiljevic, Z.; Svensson, R.; Shannon, D. Immigration and crime: A time-trend analysis of self-reported crime in Sweden, 1999-2017. Nord. J. Criminol. 2020, 21,1-10. [CrossRef]

113. Tönnies, F. Community and Society; Harper and Row: New York, NY, USA, 1963.

114. Arber, S.; Ginn, J. Ageing and Gender: Diversity and Change. Soc. Trends 2004, 34, 1-14.

115. Henning, C.; Âhnby, U.; Österström, S. Senior Housing in Sweden: A New Concept for Aging in Place. Soc. Work Public Health 2009, 24, 235-254. [CrossRef]

116. Cook, M. Using urban woodlands and forests as places for improving the mental well-being of people with dementia. Leis. Stud. 2020, 39. [CrossRef]

117. Heu, L.C.; Van Zomeren, M.; Hansen, N. Lonely Alone or Lonely Together? A Cultural-Psychological Examination of Individualism-Collectivism and Loneliness in Five European Countries. Personal. Soc. Psychol. Bull. 2019, 45, 780-793. [CrossRef]

Publisher's Note: MDPI stays neutral with regard to jurisdictional claims in published maps and institutional affiliations. 